\title{
atrente \\ Context-Sensitive Urban Research on Energy-Related Chal- lenges in Housing: Sociocultural and Spatial Dimensions in Bulgaria
}

\author{
Elena Dimitrova ${ }^{1 *}$, Milena Tasheva-Petrova ${ }^{2}$, Angel Burov ${ }^{3}$, and Irina Mutafchiiska ${ }^{4}$ \\ 1 University of Architecture, Civil Engineering and Geodesy, Sofia; eldim far@uacg.bg \\ 2 University of Architecture, Civil Engineering and Geodesy, Sofia; tasheva far@uacg.bg \\ 3 University of Architecture, Civil Engineering and Geodesy, Sofia; burov_far@uacg.bg \\ 4 University of Architecture, Civil Engineering and Geodesy, Sofia; irnamt far@uacg.bg \\ * Correspondence: eldim_far@uacg.bg
}

\begin{abstract}
Stemming from the Bulgarian case study developed within a European research project (ECHOES, Horizon 2020), the paper discusses the links between: (a) the urgent need to operationalize EU energy transition policy in the housing domain; (b) the complexity of factors influencing the policy implementation in different contexts - geographical, economic, and technical but also social and cultural; and (c) the important role of the urban level in policy implementation. Under the specific spatial planning context of Bulgaria, the local collective energy-related decision-making in the housing field evolves through the interaction - formal (at the municipal level of governance) and informal (individuals, households and homeowners' associations taking decisions on self-organization and collective action). The authors claim that interdisciplinary context-sensitive research would contribute to a better understanding for the ongoing energy-related decision-making processes at the local level and would enable the development and implementation of effective and efficient policy instruments in support of energy transition in the housing sector in Europe.
\end{abstract}

Keywords: energy transition, qualitative research, housing, homeowners' associations, collective decision making, leadership-as-practice, Bulgaria

\section{Introduction}

Energy transition, as part of the global effort addressing climate change, is nowadays a field of growing concern at all policy levels [1, 2, 3, 4]. Based on an interdisciplinary empirical study, this manuscript discusses the spatial and sociocultural dimensions of the EU-driven energy transition process in the housing domain of Bulgaria. Setting a focus on multifamily residential buildings, the study outlines the need for better understanding the tensions and opportunities emerging under a specific urban context during the implementation of a common EU strategy. ECHOES interdisciplinary research project [5] aimed to analyse people's responses to energy-related policies. Energy in buildings was one of the project three main foci, and Bulgaria was the only East European country among the eight countries addressed by the study (alongside Norway, Austria, Germany, Spain, and Turkey). The Bulgarian team was the one with urban planning expertise in a multidisciplinary research consortium, also including experts in sociology, psychology, economics and management, civil engineering, etc. ECHOES thus provided a chance for studying the national process in the housing field as part of a multidimensional European process but also resulting from peculiar historic development, material environment and urban culture. Lifestyles, memories, and attitudes evolving in space and time, were expected to influence the energy-related choices made at the local level - personal as well as collective ones. Section 2 provides a brief overview of active EU policy and research addressing the broader context of energy transition and the related planning and governance aspects in 
the housing sector. Section 3 presents the aim, scope, and methodology of the empirical study, linking the local action undertaken by informal and formal collectives to the specific spatial and sociocultural factors in the urban context of Bulgaria. Section 4 presents the research results concerning the identified spatial and socio-cultural factors influencing energy-related local decision-making and action in the housing field in the country, and Section 5 discusses the regional peculiarities of the urban process - the locally emerging challenges to energy transition and the evolving collective capacity of individuals as part of collectives to face them in the Bulgarian cities of today. Conclusions are drawn in Section 6 about the impact of the sociocultural and spatial context on the residents' energyrelated behaviour, decisions for collective action, and on the emerging leaderships in the process for energy-related transformations. Further context-sensitive urban studies are claimed important to support the effective implementation of EU policy under diverse sociocultural and spatial context in Europe.

\section{The Urban Dimensions of Energy Transition: Policy and Research Framework}

\subsection{Energy transition on the path to urban sustainability}

The topic of energy transition, closely linked to the global action for climate change adaptation and mitigation, is nowadays claimed increasingly urgent. A broad framework provided by numerous policy documents adopted at the global level since 1992, links energy with sustainable development goals, housing strategies, and climate change, e.g., Agenda 21, UN SDGs 2030, Paris Protocol, The Glasgow Climate Pact, 2021, etc. When initiating in 2006 the adoption of the Strategic Energy Technology Plan (SET Plan), the European Commission explicitly acknowledged the need for taking into consideration the social and economic dimensions of the process, including the behavioural changes and societal perceptions with an impact on energy consumption [6]. The Energy Roadmap 2050 [7] also stated in 2011 that the path towards a new energy system has a social dimension that requires encouraging social dialogue; it claimed that "not only the energy system but society as a whole needs to be dramatically more energy efficient". It also pointed to the need to answer questions "to what extent urban and spatial planning can contribute to saving energy in the medium and long term". In 2015 the updated SET Plan emphasized again that the successful energy transition in the EU would require a better understanding of the factors influencing the interaction of people with the energy system. An explicit accent was set on the energy dimensions of various lifestyles and the opportunities for influencing consumers' behavioural patterns. It seems however that a comprehensive understanding about the complexity and interconnectedness of all factors influencing the process at the local levels is rather missing. The urban dimensions of the process, such as location and morphology of the built environment, have been mentioned, mainly in relation to needed information on the functioning of energy efficient buildings and neighbourhoods in the carbon-neutral cities of the future [8]. Research has demonstrated a growing interest in the link between energy consumption and the way of life during the recent two decades [9, 10, 11]. In 2007 Martiskainen [12] outlined three types of factors influencing energy consumption: inside (beliefs, attitudes, and values), outside (institutions, regulations, and social context), and habits/ routines (automatically undertaken action). Since the early 1990s some publications have focused on the importance of emotional, routine, and social aspects of energy-related behaviour $[13,14,15]$. The recent decade witnessed a growing number of studies on consumers' energy-related decision-making and behaviour, stemming from the evolving awareness about climate change and related risks for individuals and communities $[16,17]$. There has been also a continuous effort to mobilize local action and develop urban strategies and action plans aimed at climate change mitigation and adaptation. These have included planning measures for increasing the energy efficiency (EE) of buildings and reducing $\mathrm{CO}_{2}$ emissions: pilot projects have convincingly demonstrated the considerable potential of integrating energy efficiency considerations in the planning of residential urban units, e.g., Skaftkärr, in the City of Porvoo, Finland, one of 
several EU transdisciplinary initiatives, which have developed a variety of decision-supportive urban planning tools, user interfaces, and business tools, to optimise the planning of neighbourhood energy infrastructures, e.g., IDEAS project, 2012-2015 [18]. Research on the link between the urban context and the energy consumption of buildings, however, have remained focused on theoretically defined values [19] and are still largely unconscious to the broader sociocultural and spatial factors influencing inhabitants' individual and collective energy-related choices. Nowadays, urban practice has mobilized a lot of effort in involving local communities into an interactive process of platform-based cumulative knowledge exchange in the field of energy efficiency and climate change [20].

\subsection{Energy-related challenges in the housing sector}

The housing sector provides a variety of energy-related challenges for several reasons the considerable share of energy consumption in the sector and its key impact on people's quality of life; the needed, yet often insufficient or lacking technical expertise by a variety of actors involved in a long chain of decision-making steps; and the need for a long-term clear vision and strategy for action, collectively agreed upon. The urban level of housing has been often left out of the scope of research interest for similar reasons - research either focused on the national level, providing the framework policy documents and progress milestones or limited to addressing energy-related characteristics of the separate building as a basic physical and social unit. The influence of particular social and cultural context on the behavioural modes and value-based choices of various groups - from households to communities - is currently increasingly visible but has been only partially studied [21]. New accents were added in 2018 when EU policy was already largely sensitive to the importance of the human factor, yet the collective character of living in the city and the influence of the local sociocultural and spatial context still seems underestimated [22].

\subsection{Energy-related collectives and local decision-making in the housing field}

As early as 2013, when analysing EU energy policy implementation, experts claimed that a change of consumers' energy-related behaviour is urgently needed [23]. People-centred approaches in the energy field have considerably evolved during the years in line with a more general sensitivity to the cultural dimensions of development increasingly acknowledged during the last two decades. From a social perspective, the term "culture" stands related to the values and symbols through which people understand their world. The Universal Declaration on Cultural Diversity reaffirms that culture should be regarded as 'the set of distinctive spiritual, material, intellectual and emotional features of society or a social group' [24]. Culture is not only claimed to create territorial identity as a crucial feature of social cohesion, but also to provide a framework for sustainable development policies because it could be expected to facilitate actors' understanding for the strategic goals of the undertaken interventions $[25,26]$. ECHOES research set an explicit focus on energy-related perceptions and concepts of different actors and different decision-making levels. The undertaken literature review confirmed a broadly shared understanding that achieving energy transition would require a substantial engagement of energy consumers in addition to technical or governance development. ECHOES reported an observation that "policies are largely ignoring the social connectedness of decision-makers both horizontally to other decision makers on the same level and vertically to decision makers higher or lower in the hierarchy". The recommendations made on policy improvement, included the need for understanding the cultural narratives about energy use and their historical roots in order to improve the policy measures targeted at different social groups. Regarding individuals as members of collectives with specific set of values and attitudes was considered crucial in understanding the formal and informal decision-making process [27].

\section{Research aim and Methodology}


Although indirectly included in the structure of decision-making levels and collectives, the spatial and socio-cultural characteristics of the urban context where energy-related policy and action evolves was not explicitly addressed in the ECHOES project. The project provided however the framework and data basis for the current study, and the motivation to interpret ECHOES research results about Bulgaria to outline and conceptualize the locally specific factors influencing energy-related collective action as framed by the national legislation and policy documents and enabled through the decision-making process of the homeowners' associations (HOAs), legally empowered in the country in 2009. The influence of material factors in space - settlement typology, location in the urban structure, and building types, was studied alongside the cumulative effects of the sociocultural factors evolving in time - energy memories, values and attitudes, and energyrelated lifestyles (Fig. 1).

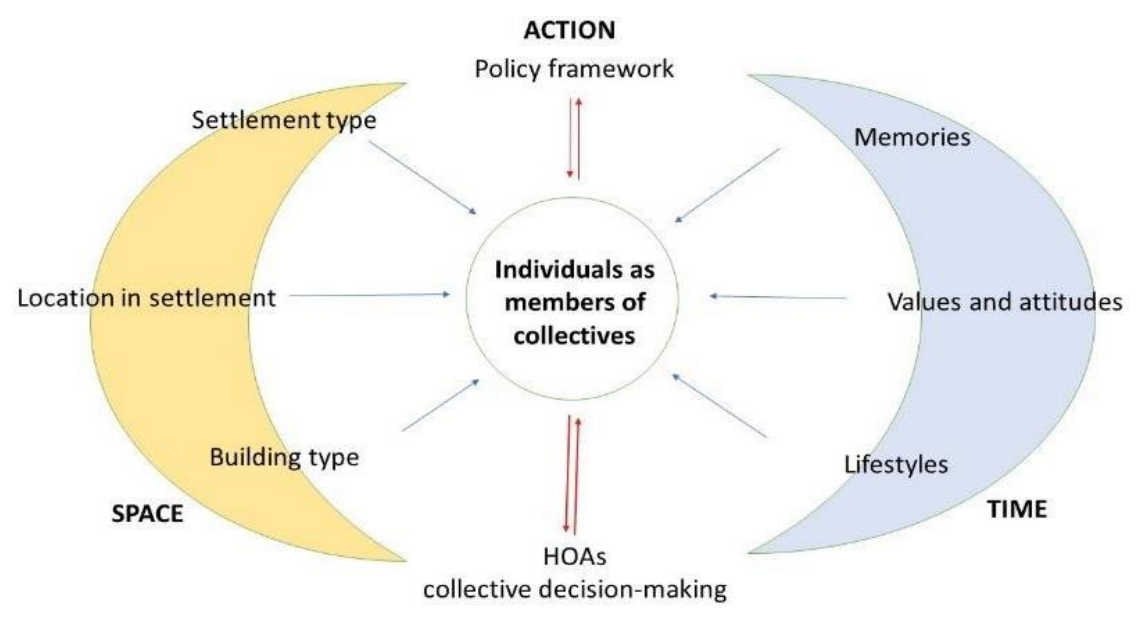

Figure 1. Factors influencing Individuals as members of collectives in the action for energy transition in the housing field (source: authors)

Starting from the study of the Bulgarian casestudies within ECHOES project, the current manuscript aims to outline the complexity of factors in space and time with an impact on energy-related local collective action at the urban level with an explicit focus on multifamily residential buildings. It addresses three groups of issues, namely: (a) policy framework, (b) spatial context, and (c) actors at the local level.Four key aspects of the quality and energy-efficiency of the housing environment are generally regarded - lighting, heating \& cooling, retrofitting, and the implementation of renewable energy sources (RES). The main research question concerns the context-specific strengths and constraints for effective energy transition at the local level in Bulgarian cities. The study builds upon ECHOES typology of energy-related decision-making collectives [28], the 'energy memory' concept [29], and the comparative analysis of 'energy-related lifestyles' [30]. It is based on the results of the mixed-method approach applied by ECHOES project: qualitative studies (development context, research and policy state-of-the-art review, discussion panels, focus groups, structured interviews) and quantitative ones (comparative regional and urban statistics; international survey on all European countries, including Bulgaria). It takes into consideration the individuals' energy memories shared among 12 participants in a discussion panel in Sofia in 2018 and the inhabitants' lifestyles and preferences addressed by a two-stage survey, followed by three focus groups (two in the capital city of Sofia and one in the town of Pazardzhik), each group with different levels of energy consumption. The study of HOAs' collective decision-making processes is based on the results of three focus groups with representatives of decision-making bodies in housing units and at municipal and national levels) [31], three case studies of D6.2 HOAs' energyrelated activities in Sofia [32,33], and a set of semi-structured interviews with various actors at the municipal level in the city of Burgas [34], all organized in the period 2017- 
2018. The study is explicitly focused on cases where collective action has been already undertaken and the participants themselves have estimated it as partially or fully successful. The influence of three groups of factors is considered: (1) the national housing policy and spatial planning regulations framework; (2) the spatial framework of urban development - settlement and housing typology; and (3) inhabitants' socio-cultural identity evolving in time - self-stated lifestyles, values, and energy memories. These are related to the residents' estimated motivation and capacity for self-organization and collective action in the multifamily housing units.

\section{Societal and Energy Transformations in Bulgaria from mid-1980s to 2020}

\subsection{Energy-related processes at the national and local level}

The literature review outlined several periods in the development of the national energy system within a broader socio-economic and political context. The system built up until mid-1980s was state-owned, centrally managed and based on conventional energy sources (local coal, imported oil); the electrification of all the settlements in the country was accomplished till early 1960s; district heating was provided and strongly relied upon in the newly built large housing estates in Sofia and the largest cities; a nuclear power plant (NPP) was set into operation in 1974 to meet the rising energy demands of both industry and domestic consumers; a relatively high share of energy based on renewables was achieved through the hydropower stations built in the 1970s. In early 1980s it seemed relevant to imagine Bulgaria as an energy hub based on nuclear, coal and hydropower plants [35, 36, 37]. A complex chain of events during the years 1984 - 2020 influenced however societal life and value systems, and energy culture and behaviour. Five periods could be outlined within the 30-year long time span regarding the energy memory in Bulgaria: (i) mid 1984-1989; (ii) 1990-1999; (iii) 2000-2006; (iv) 2007-2014, and 2014-2020.

The first period (1984-1989) coincided with the so-called Perestroika in the Soviet Union. The changing energy policy of the Soviet Union and the reduced energy supply to Bulgaria resulted in abrupt changes in the previously substantial energy support - the imported energy was considerably reduced and later re-negotiated at higher prices [38]. Bulgarian government attempted to provide foreign currency inflow through the sale of electricity to neighbouring countries; that unluckily coincided with unfavourable climatic conditions and with breakdowns of the energy distribution infrastructure; all these finally resulted in a large-scale energy crisis during the winter of 1984-1985; an 'electricity schedule' (3 hours with and 3 without electricity) alongside limitations on energy consumption was introduced in the country [39]. In parallel, due to strategic reasons, the national infrastructure continued expanding and two new blocks of Kozloduy NPP, 1000 megawatts each were set into operation in 1993, which provided additional confidence in promising 'clean energy' at a low price.

The second period (1990 to 1999) was related to the so called "period of transition" from centrally planned to market economy in the country. The profound societal changes in early 1990s resulted in a variety of conflicting worldviews and a general lack of common societal values. Numerous hardly coordinated legislation changes were undertaken within a short period of time and influenced all aspects of life. The restitution of large urban property had a particularly negative effect in the prefabricated housing estates once built on nationalized rural land at the urban fringes. The national economy was in a debt crisis and at the edge of collapse; state enterprises were closing, most of them with restored ownership of previous owners or privatized in non-transparent way; agricultural cooperatives throughout the country were liquidated [40]. With almost no oil and gas supply Bulgarian economy was paralyzed in the winter of 1991 [41]. A continuous deficit of goods and energy had been observed in 1990 and 1991, when the Council for Mutual Economic Assistance cancelled the common currency for its member countries and Soviet 
oil and gas supplies had to be paid in western currency. Another severe political and economic crisis followed in late 1996when some major power and petrochemical plants in the country passed to private Western or Russian companies [42]. Electric utilities as well as medium and small-scale co-generation plants with district heating services were also privatized [35, 43,44, 45]. The imposed 'top-down' collective models of socialism were rejected and a deep crisis in the daily management of the commons evolved through nontransparent privatization. Uncertainty and non-transparency as well as lack of political predictability about the steps to the energy market liberalization were observed [46].

The third period (2000-2006) started with opening the negotiations for Bulgaria's accession to the European Union and ended with their finalization. The Intergovernmental Conference on the Accession of the Republic of Bulgaria to the European Union started in 2001 when the Key Negotiating Chapter No 14 "Energy" was opened; many important changes in the energy field were negotiated and introduced during the next years [47]. A series of new legislative acts, regulating energy price and dealing with other energy related issues, were adopted by Parliament (including transposition of EU law). Closing the Energy Chapter of the EU pre-accession negotiations by taking the obligation to close the nuclear power plant caused disappointment in the country due to a general feeling of national energy independency being lost. Although Bulgaria ranked at a top position for cheap energy in Europe, by 2007 it also had a considerable share of 'energy poor' consumers [48]. In 2000-2006 most households faced problems with the growing prices of heating services and non-transparent accounting and pricing methods. As the privatized electricity-distributing companies faced a massive non-payment of electricity bills in neighbourhoods populated by the Roma ethnic minority, large Roma communities were excluded from any access to the electricity network in a largely discriminative way [49].

The start of the fourth period (2007-2013) marked the accession of Bulgaria to the EU in 2007. In accordance with the pre-accession obligations of the country, two units of Kozloduy NPP were closed. Due to internationally hampered gas supply a gas crisis developed in early 2009. Two major tendencies developed in parallel: poorer households were going back to conventional heating sources such as coal and wood with a considerable negative impact on the air quality; and, in parallel, well-off and entrepreneurial people chose renewable sources (biomass, geothermal and solar technologies) to be independent from the unpredictable electricity prices. A growing number of households in the multifamily blocks of flats started disconnecting from the district heating networks and shifted to individual means of heating (e.g., air-conditioners), which additionally decreased the efficiency of the outdated district heating system. The patchy insulations of the apartments in multifamily residential buildings were estimated as a major shortcoming in the housing field resulting from the individual ownership on the dwellings and the inappropriate regulatory framework on prices. [50]. Growing tensions accompanied the heated societal debate on possible energy sources to use in future; a referendum was held in January 2013 on developing nuclear energy in Bulgaria. The lack of a clear concept about energy priorities, the non-transparent energy pricing and the high energy bills provoked citizens' protests in February 2013 and the change of government. Considerable efforts were also made for increasing energy efficiency, which was among the targets of the National Strategic Reference Framework (NSRF) for the period 2007-2013 [51]. The Energy Strategy of the Republic of Bulgaria till 2020 [52] was adopted in 2011, and the National Energy Efficiency Action Plan 2014-2020 in 2014 [53]. The Methodological Guidelines on Updating the Active Regional and Local Development Strategies and Plans, published by the Ministry of Regional Planning and Public Works [54] promoted the integral approach to regional and spatial planning as an initial step of integrating EE considerations at all planning levels [55]. The Ministry of Regional Development and Public Works (MRDPW) and the United Nations Development Program (UNDP) jointly managed the "Demonstrational Renovation of Multifamily Residential Buildings" initiative (2007-2011). A countrywide municipal network was established to support the implementation of municipal 
energy policies [56]. International collaboration supported through EC programmes a broad range of activities at the municipal level. E.g. the MODEL project (2007-2010) coordinated by Energy Cities, effectively addressed the development and implementation of Municipal Energy Programs and annual Action Plans, alongside activities for strengthening knowledge and skills for energy efficiency in some pilot municipalities, and the establishment a common municipal methodology for EE planning to be implemented throughout the country.

At the start of the fifth period (2014-2020) the issue of energy poverty came higher on the national agenda and the rising electricity price for households was strongly politicized. Statistical data from various sources and thematic reports, e.g., [57] outline the considerable share of energy vulnerable households and households below the line of energy poverty as the two important characteristics of Bulgarian society, shaping the national energy culture. The high level of energy poverty in the country was linked to the overall impoverishment of the population [58]. Energy was estimated to take $14 \%$ of the overall spending of Bulgarian households; the poorest $20 \%$ of the population were however reported to spend $17.4 \%$, while the richest $20 \%$ spent only $11,9 \%$ [60]. About $34 \%$ of the households requested prolonged payment period for their heating bills and 44,9\% could not afford adequate heating comfort. In the meantime, almost $13 \%$ of the households inhabited dwellings with leakages or moisture on the walls [59]. Thus, following the World Bank definition of "energy vulnerable households" as those spending more than $10 \%$ of their income on energy, in 2016 more than $80 \%$ of the households in the country could be qualified as energy vulnerable. A behaviour simulation regarding energy poor households outlined a broad variety of negative impacts of energy insufficiency on people's everyday life and on their quality of life in general [61]. The Investment Priority "Providing Support for Energy Efficiency, Smart Energy Management and the Use of Renewable Energy in Public Infrastructure, Including Public Buildings and Housing" [62] of the OPRD 2014-2020, Priority axis 1 (Sustainable and integrated urban development), was opened in 2017 to address energy-related urban challenges.

\subsection{Contemporary spatial context: energy-related housing development factors}

\subsubsection{Settlement typology}

In 2020 , about $72.9 \%$ of the population of the country is reported to live in urban areas [63]. Despite the balanced polycentric model promoted by the National Spatial Development Concept [64], the settlement network of the country is still characterized by a continuing concentration of the population in several large cities alongside ongoing rural depopulation and ineffective implementation of the national territorial cohesion policy. In early $21^{\text {st }}$ century, Sofia is the largest city in the country with a population of 1.3 million; density of about 150 inhabitants/ha, and a share of medium and high-rise buildings - 20\% and $18 \%$ of the total built area respectively. The four largest cities - Sofia, Plovdiv, Varna, Burgas, are still growing or preserving their population, while the rest 21 district (NUTS3) centres have been shrinking since the 2000s; towns with intermediate density, as well as the municipal centres are evenly distributed throughout the country. Most of the living rural settlements are compact and integrated into the functional urban areas. Currently, many of the almost or completely abandoned villages in the country are partially used as vacation sites (Figure 2). 


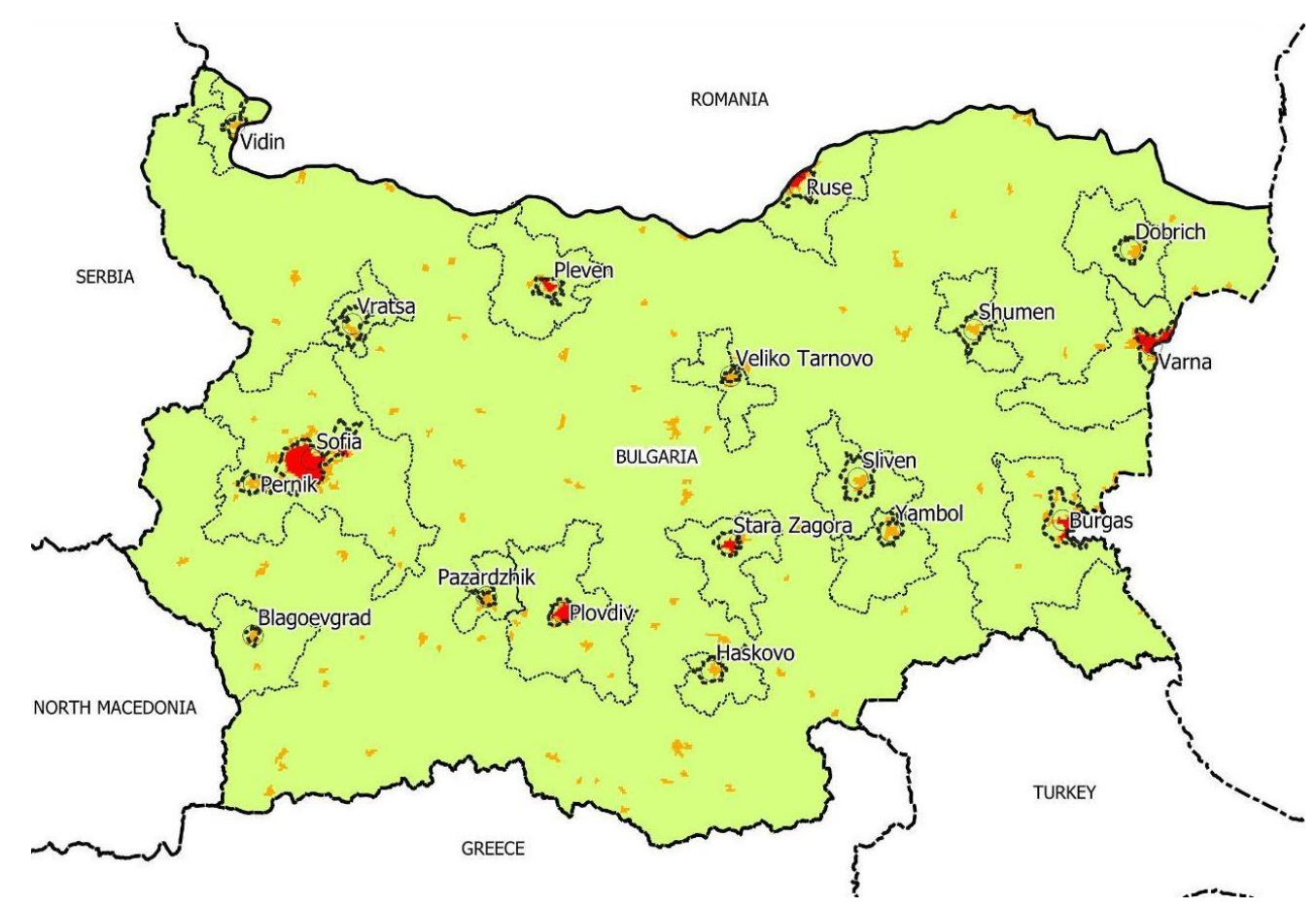

Figure 2. The settlement network in Bulgaria: City with densely populated area (red); Towns and suburbs with intermediate density area (orange); Rural thinly populated area (green); Source: authors; datasets from $[65,66]$.

The overall housing structure in the country is nowadays quite diverse - on one hand, dense and compact socialist housing estates alongside new mixed-use urban areas and gated residential units; and considerable amount of partially empty newly built blocks of flats, sprawling suburbs, and rarely visited old family houses in the countryside, on the other hand. This has a lot of implications for urban regeneration and energy efficiency and raises challenges to public policy at the national and reginal level to effectively address housing quality deficiencies and energy poverty.

\subsubsection{Urban residential areas: location, morphology, and buildings typology}

Historically, Bulgarian cities and towns have followed the European model of compact monocentric development with vital multifunctional city centres and public transport services strongly relied upon till the 1990s. The prefabricated housing estates and the large industrial zones at the peripheries are among the key physical elements of the urban legacy from socialism [67]. While at the very beginning of the post-socialist development the large industrial enterprises were largely closed and/or privatized, and functional conversion envisaged, the multifamily residential buildings in the large cities continued functioning and still provide shelter to a considerable share of the urban population today. The highest construction rate of residential buildings - a total of 324480 buildings (56 \% of them in cities), was reported in the period 1960-1969. The largest total useful area of the residential buildings, predominantly multifamily buildings in urban areas, was provided in the two decades between 1970 and 1989 - about 551 million $\mathrm{m}^{2}$ in each of them. Residential buildings of prefabricated panels comprise $19 \%$ of the total useful floor area $[68,69]$ and $27 \%$ of all the housing units in the country. They provide shelter to 2 million Bulgarians [70]. The high urban concentrations of people in the large housing estates had also resulted in high concentration of energy consumption there and complex challenges to energy-saving measures stemming from the scope of technological issues requiring relevant expertise; the large number of inhabitants of diverse social status who needed to undertake collective action [71]. The share of the privately owned dwellings is approximately $98 \%$.Most of the buildings entered the $21^{\text {st }}$ century with poor energy 
efficiency, leaking roofs, damaged facades with fallen plaster, and leaking water and sewage pipes in the basements. Their refurbishment required major capital repairs of high costs, which most of the homeowners could not afford. No energy efficiency measures were implemented in over $60 \%$ of the privately owned dwellings until 2011 , and the undertaken measures were mainly limited to upgrading the windowpanes.

\subsection{Energy-related national policy in the housing field}

As stated in the new National Integrated Energy and Climate Plan, Bulgaria is nowadays committed to striving for energy savings in the final energy consumption by focusing on the improvement of the energy performance of buildings and on energy generation, transmission, and distribution [72] (p.16). The optimal utilization of energy from the environment and keeping the thermal comfort in the dwellings through the whole year could be clearly traced in Bulgarian cultural tradition. Although unwritten, these traditional principles have been respected and explicitly addressed by the formal documents regulating the energy efficiency requirements to contemporary residential buildings since 1964. Until 1999 the normative values for energy consumption, were defined after calculations based on the outside and inside temperature of the walls, depending on the type of the building structure. Mandatory U-values and measurement of the magnitude and rate of heat losses for windows and doors were introduced in 1999; however, in 2005 they turned to only recommended. Recent analyses indicate an actual energy consumption less than half of the "normalised" consumption for the indoor microclimate in residential buildings, mainly due to the low income of the households and the voluntarily accepted lower level of comfort to reduce energy-related expenditures [73].

The review of the legislative framework in the field of energy efficiency in the housing structures outlines a consistent national policy in support of the households' action for energy efficiency through the Homeowners' associations (HOA) required by the Condominium Act since 2009. The policy implementation however has numerous problems and barriers related to the management, technological and socio-cultural dimensions of the process. Alongside, an obvious lack of political will was identified for officially adopting the National Housing strategy, which was expected to provide an integral frame for addressing challenges, including general and energy poverty, and the access to a dwelling for the most vulnerable groups of society. Public debate and criticism has addressed funding approaches, and the mechanisms of implementation monitoring and evaluation. Considerable positive development in the housing field should be also acknowledged - till 2019 EE measures were reported in 1999 buildings out of the overall 2022 contracted ones; 14,022 dwellings entered exploitation only in 2019. A resulting annual saving of $35 \mathrm{ktCO}_{2}$ and 100,674 MWh energy was estimated [74].

The currently active Energy Efficiency Act adopted in 2015 and updated in 2021 [75], followed two previous acts from 2004 and 200) with the same subject. It is coherent with EU regulations in the field and envisages next documents and actions aimed at energy efficiency in energy generation, transition, and distribution. The EEA addresses energy use in SME, industrial enterprises, public and residential buildings, and the transport sector. The key documents explicitly related to the introduction of energy-efficiency measures in the housing sector till 2020 comprise the National Energy Efficiency Action Plan (NEEAP) 2015-2020 [76] with several annexes: the National Plan for Nearly Zero Energy Buildings 2015-2020 (Annex 3); the National Plan for Improving the Energy Characteristics of Heated and/or Cooled Buildings - State Property Used by the State Administration 20162020 (Annex 4), the National Long-Term Program to Promote Investments for the Implementation of Improvement Measures of the Energy Characteristics of Public and Private Buildings in the National Residential and Commercial Building Fund 2016-2020 (Annex 6); the National Energy Efficiency Programme for Multifamily Residential Buildings [77]. Although drafted, the National Housing Strategy until 2030 is not publicly available yet. 
The Long-term National Strategy for the support for the refurbishment of the national fund of residential and non-residential buildings till 2050 [78], published, yet not adopted by October 2021, is a new document introduced through the latest changes in the Energy efficiency Act with the aim to further develop the active policy instruments. The Strategy is synchronized with the National Integrated Plan for Energy and Climate [72] and the National Plan for Regeneration and Sustainability (under development). The ongoing political crisis in the country in 2021, overlapping with the Covid-19 pandemic, considerably delayed the final structuring of urban policies and their mechanisms, including the policy aimed at energy-efficiency.

\subsection{Energy-related sociocultural factors of development}

Three groups of sociocultural factors - energy-related memories, values and attitudes, and lifestyles, potentially influencing attitudes and motivation for collective action for energy transition, were outlined through a discussion panel on energy memories held in Sofia, and three workshops discussing the lifestyle and attitudes of residents' groups with various energy-related profiles - one with high and one with low profile in Sofia, and one with mixed profile in the middle-sized town of Pazardzhik. Values and attitudes were also discussed with various respondents in the three case studies (see tables 5 and 6, subsection 4.5).

\subsection{1_Energy memory}

Overall, 13 citizens of different age and gender and with different cultural, social, economic background were invited to an ECHOES discussion panel in Sofia in December 2017 to share and discuss their energy memories and their perception on energyrelated challenges in their personal life in the period 1984-2017 (Fig. 3).
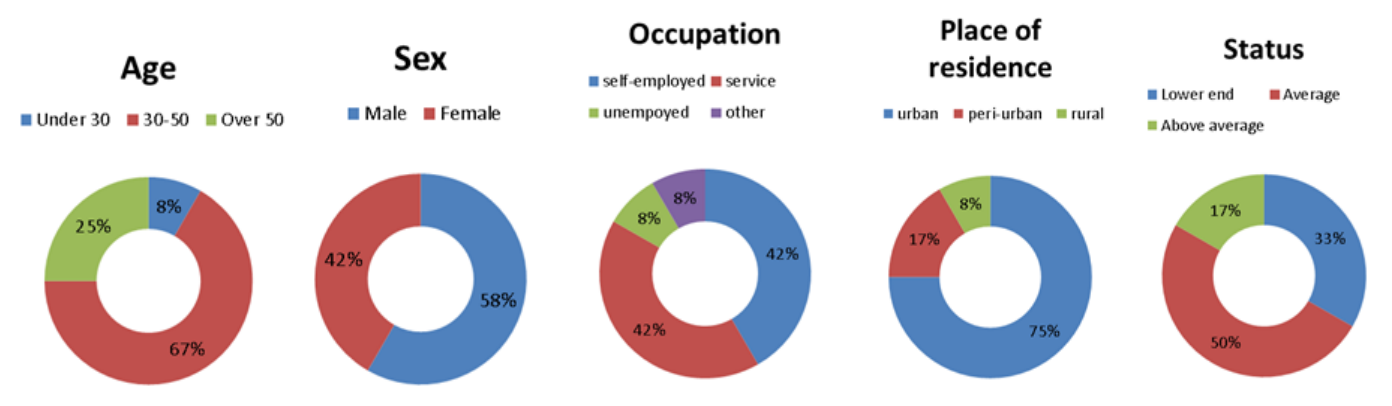

Figure 3. Typology of participants in the discussion panel (source: authors)

Three questions were included in the invitation letter: (1) When and on what occasion did you come to think about the energy you use? What was the most important moment for you / your family during the last 30 years regarding energy? (2) What was the most difficult moment that made you change your energy use and how did it influence your quality of life? (3) Are we reasonably using energy today? What do we need in Bulgaria today to be more energy efficient - technological innovations, regulations, educational campaigns, or something else?

The periodic interruptions in daily electricity supply (the so-called electricity schedule) in mid-1980s and early 1990s alongside the rise of the electricity prices in 2013 were outlined as the events with a key impact on the energy memory of the panel participants.

There were also memories about the abundance and accessibility of energy under socialism with no perceived need for saving it; some participants also outlined the contrast in 1980s between the countryside and the capital city of Sofia, the energy supply of which 
had been a national priority: "We lived in Varna when I was a child, it was never too hot anywhere, there were times when there was no money and the whole family slept in one room, not to heat two rooms or more" (R13); "Coming to the student hostel in Sofia I felt like entering paradise - windows opened and the central heating working at maximum, all the possible lamps switched on; just nobody thought that there should be any saving." (R10); "In the Student Town it was really a different world; I never imagined I would be able to take a shower as long as I wanted without running out of hot water. The same thing was with the heating - it was always warm there; until getting back to your native town and to the stove - it just gets warm when you must go to bed, which is not very good and effective (R11).

Several participants shared the shock experienced in 1985: "I clearly remember the electricity schedule of 1985 as I lived then on the 16th floor - when the electricity was switched off there was no lift, no water (relying on pumps) and no central heating - nothing. And it reminded me of the opposite situation before that - the heating set centrally to a maximum and all of us staying with half opened doors or windows to cool the room" (P4). The younger participants rather remembered the second electricity schedule (1990-1991). Memories differed by age groups: "Although my mammy has mentioned an electricity schedule in the winter of 1984 when I was just born, I remember quite well the schedule in early 1990s. I was a child then and our favourite TV episodes of the Ninja Turtles were usually interrupted by the schedule. My father was then smart enough to bring the battery from the car so that we would not miss the film" (R3). Children's memories understandably differed from adults': "I was too young then to think about energy spending; on the contrary, it was for me an exceptional event, it was top interesting - firstly, all the family gathered around some light, neighbours were coming and telling interesting stories and that was for a child a marvellous experience" (R7); "Stopping the electricity started a party - candles were burning, the neighbours were gathering, somebody bringing a guitar, children were playing together. It was cold, but we, kids, enjoyed the excitement" (R13). It also appeared that electricity schedules had some long-term impacts on the energy culture of children: "I was probably 7-8 years old and could not understand how it was possible not to have electricity in the net. I was going around the flat and switching off the lamps all the time as I thought that would keep some electricity for later." (R1)

The energy vulnerable groups responded to the rising of district heating prices by the search for cheaper and more effective heating solutions: "The bills we got were really too high for our family budget, and then it was decided to discontinue the use of the district heating and to switch to electricity - and there was again the joy in my family that we would finally be able to control energy use - to know how much we use and how we save. I remember coming home after school and after work, waiting for the apartment to warm up, yet it was not the case on the $14^{\text {th }}$ floor and with old wooden window frames" (R5).

The identified key events differently shaped today's individual energy practices of the participants. There was anyway a generally increase of awareness about the benefits of increasing energy efficiency and motivation for searching relevant soft and infrastructure measures to achieve it. Particular steps strongly depend on people's professional background and capacity for action: "I've put automats on the doors at home not to stay open. Also, from this winter I installed smart radiator valves - they can be programmed so that the temperature could be $23^{\circ} \mathrm{C}$ at $6 \mathrm{o}^{\prime}$ clock in the morning. I do not know yet whether it will have a real effect on the bill, but it's comfortable because we sleep at 18 degrees, we wake up warm in the morning; I also made the valves to shut off during the day when we are not at home (R11). Inevitable changes in the energy needs and consumption patterns in the course of individual and households' lifespan were also mentioned: "I've lived in a single-family house for 40 years. I've had all kinds of heating at home. [...]. Then we took a loan and installed the local heating (relying on coal). It was the best period with the heating as it was warm everywhere. Then we made insulation of the house and changed the windowpanes, and it was wonderful [...] Now we are just the two of us, we are getting old and there is nobody to take care of the coal" (R8). 


\subsubsection{Lifestyles}

Three focus groups were organized to outline the peculiarities of energy-related lifestyles of three groups of citizens with varying energy profiles identified in advance - one with high energy profile (HEP) and one with low energy profile (LEP) in Sofia, and one with mixed energy profile (MEP) in a middle-sized town in the countryside. The discussions on the routine daily activities covered energy aspects of mobility, heating/cooling, food and cooking, and everyday working patterns. Three transportation modes were mentioned during the focus groups - by car, by public transport and on foot. Differences identified in the daily movement were between the group of HEP (mainly by car and often by public transport), the group of LEP (mainly relying on public transport or walking), and the MEP group (walking or by private car). The use of private cars was not necessarily related to a high energy profile, it was rather motivated by considerations of convenience, avoidance of health risks and saving time. A car was also used in the absence of reliable and convenient public transport. Sofia metro was highly valued in terms of movement speed and comfort in the capital city. Walking for 15-20 minutes appeared popular among the representatives of all the groups; overcoming longer distances on foot was perceived as too time-consuming. Cycling was not accepted by HEP participants due to perceived health risks in the unfavourable urban environment in Sofia. Heating/cooling and home-based activities were mentioned to rely mainly on electricity and central heating; implementing intelligent heating measures was considered an opportunity to optimize costs. Cooling was estimated as necessary, yet air conditioners were reportedly avoided for reasons related to comfort and health; shading and insulation with other measures were preferred instead. Participants in all the three groups reported often going out for eating on weekdays, motivated by convenience and time-saving considerations. For LEP participants, eating at home was associated with saving natural resources; for those from the MEP group the leading motivation for the evening meal at home was the traditional family communication. Electricity, sometimes combined with gas, was mentioned as the main energy source for cooking; raising young children was stated to significantly increase the energy demand. Reported changes in the everyday work organization included the introduction of home-based work and flexible working hours, resulting in the broad introduction of computer and office equipment and to additional energy use at home. Common characteristics of the behaviour patterns and the resulting energy needs were found in the three groups of the study. The study identified a daily rhythm flexibility, enabling the adaptation to changing employment requirements and family composition (the appearance of children); however, the family tradition of having evening meals together remains stable. Computers have become widespread in everyday life. Electricity is the predominant energy source for meeting daily needs. Cooling in summer is considered important in view of climate change, but participants in all the groups prefer shading and insulation to prevent overheating, not air conditioners. Walking is popular among all participants, but in the large city it is sometimes too time-consuming; the participants in the HEP group prefer using their cars in the city instead of the inconvenient public transport; all respondents predominantly use cars for out-of-town trips. Some specific characteristics of the groups were also identified: (a) In the smaller town, more traditional family patterns of everyday behaviour are preserved, although changes are also taking place there. Eating at home together in the evening is mentioned as very important. (b) Pazardzhik was the first city in the country with gasification undertaken in late 1990s - due to rapid collective action, many of the participants had gained access to cheap energy for their households and were aware of the advantages. (c) The participants in the MEP group are most closely related to their suburban region; they are most sensitive to the topics of healthy living and healthy eating; there is a continuity of traditions there. Many of the respondents are engaged in agricultural activities and interested in nature-based solutions in home construction (local natural materials, solar panels, wind energy, etc.) and in agriculture (the biodynamic concept, drip irrigation, etc.). 


\subsubsection{Values and attitudes}

The discussions on life decisions were mainly focused on choices made about places of residence and types of buildings. Most of the participants in the focus groups shared that they lived in their own homes, which corresponds to the peculiarities of home ownership in the country. The factors influencing participants' satisfaction and/or dissatisfaction with the living environment and possible energy-related considerations when choosing a home were also commented. The general perceptions and attitude towards energy and climate change were linked to the participants' motivation for practical action (Table 1).

Table 1. Energy aspects of strategic life decisions related to housing.

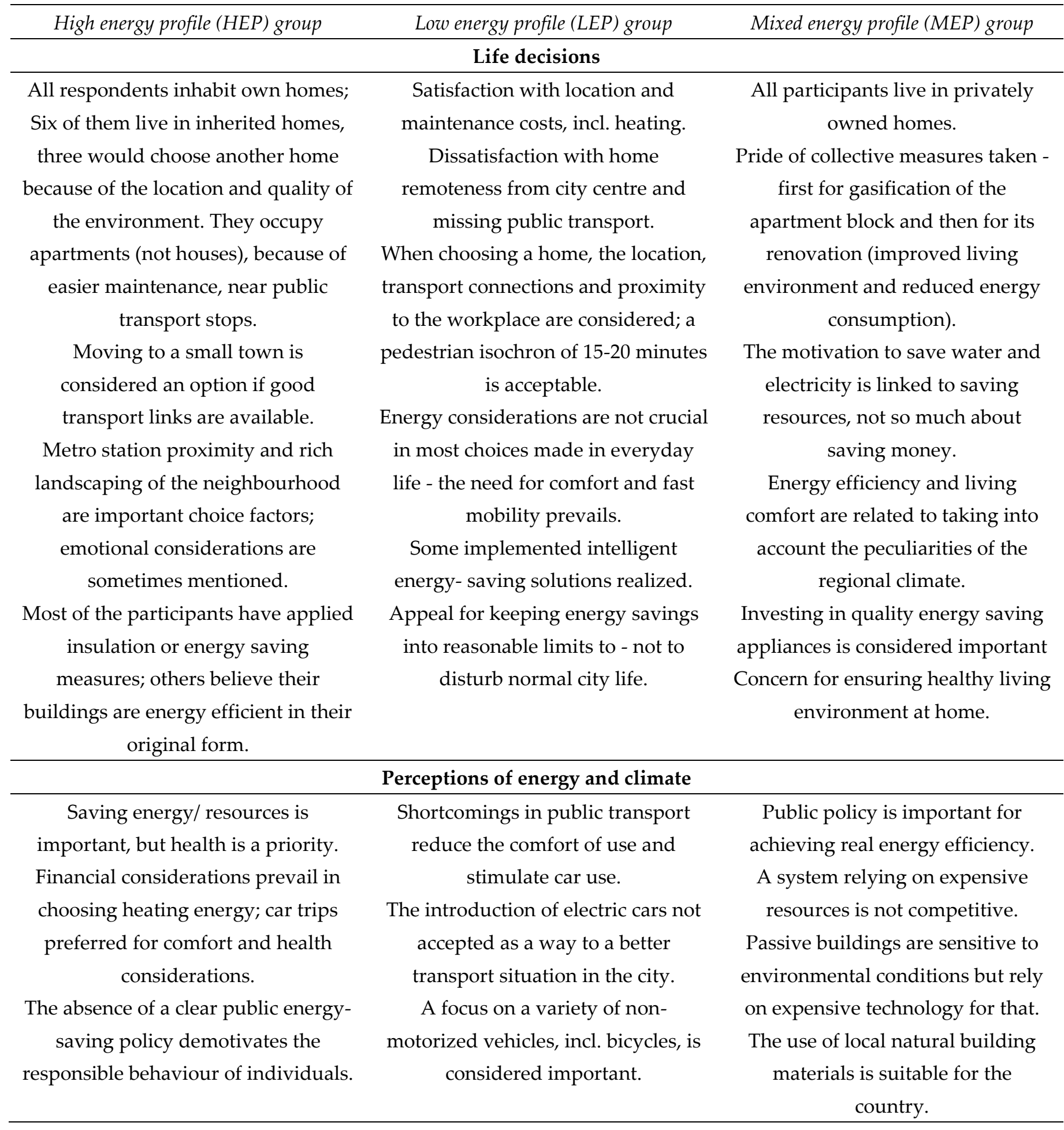




\subsection{Homeowners' associations (HOAs) as local collective decision-making bodies}

The study of Homeowners' associations (HOAs) as local collective decision-making bodies was based on three case studies in Sofia: multifamily houses located in the quarters of Slatina (Casestudy 1), Oborishte (Cs2), and Strelbishte (Cs3). The cases were related to the typology of urban settings and residential buildings, years of construction, and by funding typology (funding rules and availability of sources. The semi-structured interviews sought for information about undertaken collective action, energy-related targets, Initiator, leadership, key actors, interactions and contributions, measures applied and action results (Table 2 ).

Table 2. Three Sofia casestudies: energy-related action and results in the urban context

\begin{tabular}{|c|c|c|c|}
\hline & Cs1 Slatina quarter & Cs2 Oborishte quarter & Cs3 Strelbishte quarter \\
\hline \multicolumn{4}{|c|}{ Empirical research steps } \\
\hline \multirow{8}{*}{$\begin{array}{l}\text { Information } \\
\text { sources, contact } \\
\text { type, number, } \\
\text { and type of } \\
\text { respondents }\end{array}$} & Semi-structured & Semi-structured interviews: & Semi-structured interviews with \\
\hline & interviews: & - ex deputy mayor of the & HoA members (all engineers): \\
\hline & - a member of a & administrative district. & - HoA Head/ manager; \\
\hline & specialized NGO & - an energy agency expert, & - Proactive member. \\
\hline & methodologically & - three flat owners in two & - Active and supportive \\
\hline & supporting EE & buildings renovated through the & member. \\
\hline & initiatives. & project & - Skeptical and partially active \\
\hline & - an EEA ${ }^{1}$ expert & & member. \\
\hline \multicolumn{4}{|c|}{ Urban context } \\
\hline \multirow{6}{*}{$\begin{array}{c}\text { Typology of } \\
\text { urban settings } \\
\text { and buildings, } \\
\text { period/ year of } \\
\text { construction }\end{array}$} & A 15-storey multifamily & A 5-storey building with 10 & 3 semi-detached 8-storey \\
\hline & building with two & dwellings built in 1930s, recently & prefabricated panel blocks with \\
\hline & entrances, 120 flats, & refurbished; a traditional & 6 entrances and 112 flats built in \\
\hline & Located in a & residential quarter in a dense & $1967-1969$ in the southwestern \\
\hline & dynamically developing & urban structure close to the city & part of the city,. \\
\hline & neighbourhood & centre; & \\
\hline \multirow{5}{*}{$\begin{array}{c}\text { Funding } \\
\text { rules and } \\
\text { availability of } \\
\text { sources }\end{array}$} & Own sources: & $100 \%$ DPRMRB 2 grant for common & $100 \%$ grant by the National \\
\hline & homeowners decided to & parts renovation; owners - $20 \%$ of & Program for Energy Efficiency \\
\hline & invest not-spent & the dwelling expenses; & of Multi-Family Residential \\
\hline & construction money for a & Municipality - adjacent area; EU & Buildings \\
\hline & photovoltaic system & funding ${ }^{3}$ for a roof solar system. & \\
\hline
\end{tabular}

\section{Undertaken collective action}

\begin{tabular}{cccc}
\hline Action interval & 2013 - 2017 & 2010 - 2014 & $2014-2016$ \\
\hline $\begin{array}{c}\text { Energy-related } \\
\text { targets }\end{array}$ & A 28-kW photovoltaic & Design and installation of a roof & Building upgraded from energy \\
& system for electricity & solar system for hot water; & performance class E to C. 309 \\
& generation, estimated & building certified after renovation & $\mathrm{kWh} / \mathrm{m} 2$ initial primary energy \\
& output 35 Wh/year & as energy class A+ & consumption and 194 kWh/m2 \\
& & & after rehabilitation.
\end{tabular}

\footnotetext{
1 EEA - Energy Efficiency Agency

2 DPRMRB - Demonstration Project for the Renovation of Multifamily Residential Buildings

3 Staccato project - 6th EU Framework Program
} 


\begin{tabular}{|c|c|c|c|}
\hline $\begin{array}{l}\text { Initiator \& } \\
\text { leadership }\end{array}$ & $\begin{array}{l}\text { A homeowner with } \\
\text { expertise in renewable } \\
\text { energy; HoA Head and } \\
\text { Managing Board } \\
\text { members }\end{array}$ & $\begin{array}{l}\text { The HoA Head; a family of two } \\
\text { elderly engineers with expertise } \\
\text { in the energy field; } \\
\text { residents with specific expertise. }\end{array}$ & $\begin{array}{c}\text { Formal: General Assembly, HoA } \\
\text { Head \& Managing Board. } \\
\text { Informal: three homeowners } \\
\text { who registered HoA; HoA Head } \\
\text { and ten proactive HoA } \\
\text { members. }\end{array}$ \\
\hline $\begin{array}{l}\text { Local key actors } \\
\text { and } \\
\text { contributions }\end{array}$ & $\begin{array}{l}\text { HoA Head and a private } \\
\text { company providing } \\
\text { electricity; each one took } \\
\text { a different role in the } \\
\text { decision implementation }\end{array}$ & $\begin{array}{l}\text { Homeowners and the HoA Head; } \\
\text { The solidarity of the collective } \\
\text { with people lacking the financial } \\
\text { resources was crucial for the } \\
\text { success. }\end{array}$ & $\begin{array}{l}\text { The district administration } \\
\text { assisted in HoA establishment, } \\
\text { the regional and municipal } \\
\text { administration - information } \\
\text { campaigns; HoA Head - by } \\
\text { involving the initially opposing } \\
\text { owners. }\end{array}$ \\
\hline $\begin{array}{l}\text { Action, } \\
\text { procedures and } \\
\text { measures } \\
\text { applied }\end{array}$ & $\begin{array}{l}\text { Clarifications on benefits } \\
\text { and risks; debate and } \\
\text { collective decision on the } \\
\text { investment; signing the } \\
\text { formal agreement; } \\
\text { selecting and installing; } \\
\text { connecting to the } \\
\text { national electricity grid. }\end{array}$ & $\begin{array}{l}\text { Homeowners' collective decision } \\
\text { for joining the project; installing } \\
\text { the solar system; building } \\
\text { certification as energy class A+; } \\
\text { monitored operation of all the } \\
\text { installations; work with HoA on } \\
\text { capacity-building for reducing } \\
\text { energy use }\end{array}$ & $\begin{array}{l}\text { Structural and energy audit; } \\
\text { issued technical passport of the } \\
\text { building; overall thermal } \\
\text { insulation of the building; } \\
\text { replacement of joinery and } \\
\text { lighting system; upgrading of } \\
\text { the central heating system, } \\
\text { changing the vertical installation } \\
\text { pipes. }\end{array}$ \\
\hline $\begin{array}{l}\text { Action results } \\
\text { and follow-up }\end{array}$ & $\begin{array}{l}\text { A collective investment } \\
\text { with guaranteed } \\
\text { revenue; a next } \\
\text { collective investment in } \\
\text { energy saving } \\
\text { windowpanes for the } \\
\text { common staircases. }\end{array}$ & $\begin{array}{l}\text { Owners' initiative - introducing } \\
\text { smart technology for distance } \\
\text { energy consumption reporting. } \\
\text { The failure of the water heating } \\
\text { system after the } 1^{\text {st }} \text { year } \\
\text { compromised the economic effect } \\
\text { of the initiative. }\end{array}$ & $\begin{array}{l}\text { Reduced energy bills, increased } \\
\text { value of the property, extended } \\
\text { life of the building; roof and } \\
\text { basement repaired. A } \\
\text { respondent mentioned that no } \\
\text { air conditioning was needed in } \\
\text { the dwelling after the } \\
\text { renovation. }\end{array}$ \\
\hline
\end{tabular}

Although the three cases differed in urban context, type of funding and number of beneficiaries, some common features were identified regarding the process: project initiation, actors involved, leadership, and overall action results. The actors' experiences during the implementation of the projects were also compared to their perceptions, feelings and estimation of the process and results - personal motivation for action, estimated challenges, expectations and disappointments, satisfaction, or dissatisfaction with results (Table 3).

Table 3. Three Sofia Casestudies: Actors' Estimation of the Collective Action Effectiveness

\begin{tabular}{cccc}
\hline & Cs1 Slatina quarter & Cs2 Oborishte quarter & Cs3 Strelbishte quarter \\
\hline Homeowner & The expectation for & The understanding that the complex & Thermal comfort; economic \\
s' personal & common economic & effects of the action will be far greater & benefits \\
& benefits, was among key & if integrated measures are applied to & \\
\hline
\end{tabular}




\begin{tabular}{|c|c|c|c|}
\hline $\begin{array}{l}\text { motivation } \\
\text { for action }\end{array}$ & $\begin{array}{l}\text { motivating factors for the } \\
\text { leader and his team. }\end{array}$ & $\begin{array}{l}\text { the whole building; the benefits } \\
\text { motivated next HoAs to join the } \\
\text { program. }\end{array}$ & \\
\hline $\begin{array}{l}\text { Estimated } \\
\text { challenges }\end{array}$ & $\begin{array}{l}\text { The communication with } \\
\text { numerous owners; } \\
\text { difficulties in coming to a } \\
\text { collective decision, lack of } \\
\text { community spirit; need } \\
\text { for own funding sources; } \\
\text { the short timeframe. }\end{array}$ & $\begin{array}{l}\text { The long intervals between the } \\
\text { submission of the application and the } \\
\text { approval of the beneficiaries, and } \\
\text { between signing the contract and the } \\
\text { start of the refurbishment, with no } \\
\text { information meanwhile were strongly } \\
\text { demotivating. }\end{array}$ & $\begin{array}{l}\text { Shortcomings in the } \\
\text { implementation and quality } \\
\text { of the refurbishment } \\
\text { measures. }\end{array}$ \\
\hline $\begin{array}{c}\text { Expectations } \\
\& \\
\text { disappointme } \\
\text { nt }\end{array}$ & $\begin{array}{l}\text { The administrative } \\
\text { barriers and delays had a } \\
\text { negative effect on their } \\
\text { relations between } \\
\text { homeowners and HoA } \\
\text { Managing Board. }\end{array}$ & $\begin{array}{l}\text { Expected savings were missed due to } \\
\text { the heating company's unwillingness } \\
\text { to amend the calculated energy prices } \\
\text { for an A+ energy class building. A } \\
\text { failure of the water heating system at } \\
\text { end of the } 1^{\text {st }} \text { operational year. }\end{array}$ & $\begin{array}{l}\text { The initiators expected an } \\
\text { easier procedure and more } \\
\text { homeowners getting actively } \\
\text { involved and contributing to } \\
\text { the process. }\end{array}$ \\
\hline $\begin{array}{l}\text { Satisfaction/ } \\
\text { dissatisfactio } \\
\mathrm{n} \text { with } \\
\text { results }\end{array}$ & $\begin{array}{l}\text { The homeowners chose } \\
\text { the benefits of an } \\
\text { investment with a } \\
\text { constant and guaranteed } \\
\text { revenue to distributing } \\
\text { small amounts of already } \\
\text { devaluated money among } \\
\text { themselves. }\end{array}$ & $\begin{array}{l}\text { Dissatisfaction with the water heating } \\
\text { company's unwillingness to change } \\
\text { the calculation methodology. The } \\
\text { water heating system failure after the } \\
\text { 1st operating year and the hiring a } \\
\text { specialized maintenance company } \\
\text { compromised the economic feasibility } \\
\text { of the project. }\end{array}$ & $\begin{array}{l}\text { Personal satisfaction that } \\
\text { one's professional expertise } \\
\text { contributed to the collective } \\
\text { benefit; a feeling of } \\
\text { belonging to a community } \\
\text { possessing the power of } \\
\text { changing things. Aesthetic } \\
\text { satisfaction. }\end{array}$ \\
\hline
\end{tabular}

A $4^{\text {th }}$ casestudy (Cs4), was explicitly focused on the interactions among the different types of actors during the NEEP-funded refurbishment of the multifamily residential houses in the city of Burgas, the $4^{\text {th }}$ biggest city in Bulgaria and the most successful one in the programme implementation with 234 refurbished buildings by 2019 (Table 4). The comparison between the results from Sofia and Burgas confirmed several common characteristics. The improvement of the energy efficiency the buildings was in all cases considered a pressing priority by the homeowners and the local administration alike. The estimated urgency of undertaking action and the announced tight programme schedules motivated local efforts for self-organization. The HOAs, legally empowered in 2009, played a leading role in the self-organization of all the homeowners' collectives. The proactive attitude of the local administration in Burgas and their decision to provide budget resource for organizing effective communication with the homeowners was crucial for the success of the programme. The shared disappointments in all the cases were mainly related to two factors: (a) the failures in the functioning of the introduced new systems due to the lowquality management, and (b) the bureaucratic barriers to acknowledging the energy-saving measures.

Table 4. NEEP implementation in the city of Burgas (Cs4)

\begin{tabular}{|l|l|}
\hline \multicolumn{2}{|c|}{ Empirical research steps } \\
\hline $\begin{array}{l}\text { Information } \\
\text { sources, }\end{array}$ & $\begin{array}{l}\text { Desk review of published data; semi-structured interviews with: Deputy-Mayor responsible for } \\
\text { construction, investments and regional development; Department Head in the municipal } \\
\text { administration in charge for NEEP implementation; HoA Head in a refurbished residential }\end{array}$ \\
\hline
\end{tabular}




\begin{tabular}{l|l}
$\begin{array}{l}\text { contacts type } \\
\text { respondents }\end{array}$ & $\begin{array}{l}\text { building, mechanical engineer dealing with design and energy audits; Engineer from a private } \\
\text { company for energy audits and design of energy efficiency measures with experience in NEEP- } \\
\text { funded projects. }\end{array}$
\end{tabular}

\begin{tabular}{|c|c|}
\hline \multicolumn{2}{|r|}{ Urban context } \\
\hline $\begin{array}{l}\text { Urban setting } \\
\text { and buildings }\end{array}$ & $\begin{array}{l}\text { About half of the municipality population resides in } 440 \text { multifamily buildings in housing } \\
\text { estates in the city of Burgas. }\end{array}$ \\
\hline $\begin{array}{l}\text { Funding } \\
\text { rules and } \\
\text { availability of } \\
\text { sources }\end{array}$ & $\begin{array}{l}\text { The programme launched at national level; joint efforts by the Council of Ministers, MRDPW, } \\
\text { Ministry of Finance, Bulgarian Development Bank; Targeted industrially built multifamily } \\
\text { houses designed before } 1999 \text { and with min } 3 \text { floors and } 6 \text { residential units. Single national call for } \\
\text { applications in 2015-2016, closed after allocated NEEP funds were utilized; no defined funding } \\
\text { per municipality; each HOA competing with all the rest in the country. HoA registration as } \\
\text { major funding prerequisite. Consent of } 95 \% \text { of the homeowners in a building required. A } 100 \% \\
\text { subsidy on structural reconstruction, strengthening or repair (after audit; renovation of the } \\
\text { common areas (roof, façade, staircases, etc.); EE measures implementation (after audit). }\end{array}$ \\
\hline
\end{tabular}

Undertaken collective action

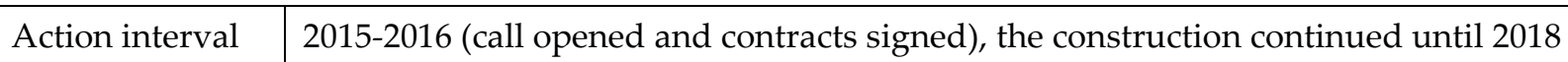

Energy-related $\quad$ Energy consumption class $\mathrm{C}$ regarding energy efficiency, heat storage and energy saving.

targets

Local initiator \& $\quad$ Leadership: Mayor, local administration, additional staff/ mediators from the Municipal leadership $\quad$ administration, HoA Heads; other actors: external contractors, private companies, independent professionals.

Key local actors $\quad$ Mayor and local administration: public procurement procedure for each residential area and

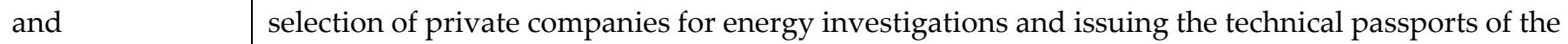
contributions buildings; informing and motivating, approval of applications, investors' supervision.

Legally registered HOAs and their Heads: submitting the HoA applications to the municipal administration, communicating with residents before and during the refurbishment;

External contractors / private companies: energy investigation, preparation of energy audits and technical passports, design, construction, technical supervision.

\begin{tabular}{|l|l|l}
\hline $\begin{array}{l}\text { Action, } \\
\text { procedures and } \\
\text { applied } \\
\text { measures }\end{array}$ & $\begin{array}{l}\text { Municipal budget provided for administrative support and information campaigns. successful } \\
\text { HOA managers hired by the Municipality as part of the Investor's supervision on NEEP; legal } \\
\text { foundation of the Homeowners' association, submitting HOA applications, communicating with } \\
\text { residents to provide access to balconies during the implementation of the technical measures, etc. }\end{array}$ \\
\hline $\begin{array}{l}\text { Action results } \\
\text { and follow-up }\end{array}$ & $\begin{array}{l}\text { Overall } 236 \text { signed contracts and } 234 \text { multifamily residential buildings with accomplished } \\
\text { construction works by March 2019; after accomplishing their work in Burgas, construction } \\
\text { companies were employed in other municipalities. }\end{array}$ \\
\hline $\begin{array}{l}\text { Homeowners' } \\
\text { personal } \\
\text { motivation for } \\
\text { action }\end{array}$ & $\begin{array}{l}\text { Proactive role of the municipal administration: the mayor's strong political leadership; the } \\
\text { strategic decision for spending municipal money on administrative support and information } \\
\text { campaigns. }\end{array}$ \\
$\begin{array}{l}\text { Proactive HOAs (Heads and members), estimating the provided chance for solving a complex } \\
\text { problem and eager to acquire additional EE competence - consistent efforts for initiation, } \\
\text { management, communication and awareness raising. }\end{array}$
\end{tabular}




\begin{tabular}{|l|l|}
\hline Estimated & $\begin{array}{l}\text { The tight NEEP programme schedule; homeowners' diverse background, income, and capacities; } \\
\text { large HoA collectives in buildings with up to } 190 \text { flats; the lack of experience and communication } \\
\text { skills at the municipal administration. Lack of understanding about monitoring as a systematic } \\
\text { process. }\end{array}$ \\
\hline $\begin{array}{l}\text { Expectations, } \\
\text { disappointment }\end{array}$ & $\begin{array}{l}\text { Large-scale complex measures accomplished in a brief timeframe. The sustainability of results is } \\
\text { questioned. to be considered - outlined as a major shortcoming Even modest co-financing by the } \\
\text { homeowners would motivate long-term personal responsibility. prevented owners' participation } \\
\text { in decision-making on the implementation of measures. A co-financing component recommended } \\
\text { in future to motivate long-term care and personal responsibility }\end{array}$ \\
\hline Satisfaction with & $\begin{array}{l}\text { Acquired administrative competence; new culture for communication and building trust among } \\
\text { municipal administration, designers/engineers and construction business gradually establishing. } \\
\text { The municipal action know-how on leadership, process management, and competitive application } \\
\text { process nationally acknowledged as good practice. Generated sense of community and concern } \\
\text { about the common ownership. }\end{array}$ \\
\hline
\end{tabular}

\section{Discussion}

\subsection{Identified contextual peculiarities in Bulgaria}

\subsubsection{Sociocultural factors - energy memories, lifestyles, and attitudes}

The energy topic was intertwined in a broad variety of memories identified by the study and covering all aspects of personal and societal life in the recent 35 years. The memory about the energy abundance and thermal comfort in the student hostels in Sofia under socialism, where nobody was expected to take a personal responsibility for the energy consumed, was also indicative of a broader societal perception about energy being growingly abundant and accessible and energy provision being the responsibility of the State in that period. The first electricity schedule in the winter of 1984-85 brought a changing perspective of the world - people realized that energy could not be taken for granted. The interruptions were however considered only occasional; it was still broadly considered that the State should be able to cope with the problems in due time. The second electricity schedule in early 1991 came at a moment of growing political instability and evolving societal crisis; an overall disruption of the technical and social systems supposed to maintain the normal functioning of society was going on. It was increasingly obvious that people could not rely on the State and had to find their own ways of living with the energy limitations and adapting to unexpected and lasting energy deficits. The impact of energy memories on the participants' further energy behaviour seemed to be group specific - it depended on people's diverse paths in life and professional background, the accessibility of information and the resulting awareness about energy issues. There was however a shared perception among the participants that people had never been informed about the real situation with energy supply and intended major energy projects. All of them also mentioned their active efforts to take any emerging opportunity for improving the energy efficiency of their homes. The discussion results were also indicative of a significant rupture in passing energy memories from one generation to another. The needs and lifestyles of the generations who experienced the two electricity schedules as grown-ups strongly differed from these of the younger generations - the former had been concerned about the disturbance of daily routine activities and experienced a cultural shock when realizing that the State could not be trusted even in providing basic services; the latter had been worried about the inconveniences in listening to music or watching TV. The somewhat self-ironical storytelling about surviving a difficult period during the meeting also turned into a discussion about taking responsibility well beyond the energy field. The study on 
lifestyles and attitudes confirmed that some life choices depend on the existing built environment, the public policy implemented, and the availability of technical urban infrastructure. Participants' preferences and life choices had stemmed from considerations about comfort, economic profit, and time saving. Health was a clear priority to all of them and keeping to established family traditions, e.g., cooking and eating at home, were considered important for family links. The discussion panel highlighted some important messages to urban planners and architects about optimizing the energy efficiency of the built environment in a way that respects the needs and desires of its inhabitants. According to the participants reducing the car use in everyday mobility would be possible by improving the convenience and speed of public transport. A direct link between energy efficiency and a healthy urban environment was acknowledged - in many cases, increased energy efficiency had contributed for a healthier urban environment; however, in cases of contradiction between health and energy efficiency, the requirement for comfort and healthy environment comes first at the individual and at the group level. A general awareness was shared about the need to wisely use energy and natural resources, but most of the participants considered a certain degree of comfort to be important and claimed that energy saving should be required within reasonable limits. Many participants also insisted on sharing their past experiences, which outlined the dynamic character of the socio-cultural context, the message about the dynamic character of lifestyle, which changes through life for many reasons, e.g., pregnancy and motherhood, unemployment, care for sick and elderly family members.

\subsubsection{Local action to solve energy-related problems: success factors and challenges}

Requiring mandatory management and energy efficiency standards in the housing field had been long avoided in Bulgaria despite the adopted new legislation due to being politically sensitive. Although the refurbishment of the existing multifamily residential houses had been acknowledged as a national task of urgency and high social priority, it was estimated as one of considerable complexity, too, and difficult to undertake by the owners themselves because of the costs incurred [52] (EC Fact-finding mission, 2013). A variety of funding schemes were already accessible in the country due to EU and national programmes, which mainly addressed multi-family buildings due to the high concentration of residents there. The high share of private ownership on the apartments turned to be one of the biggest obstacles in the practical organization of the process. On the one hand, the big number of homeowners of varied social and economic status in the multifamily housing units made it hard to apply differentiated selection criteria guaranteeing a fair funding distribution among homeowners of different income. The homeowners from an entire building structure were supposed to collectively apply after reaching a consensus through their officially registered associations. The 'first come, first served' principle chosen at the national level to distribute the $100 \%$ grants from the national programme among the applicants was repeatedly criticized during the study meetings and interviews as it was considered socially inequitable. On the other hand, many homeowners were initially reluctant to join because of their distrust to the State and public authorities in general, even when the benefits from the implementation of energy efficiency measures were direct and obvious, and that hampered the application of the whole collective. The major barriers mentioned by the contacted homeowners and municipal experts with a practical experience in the process had been normative and organizational, related to the lack of relevant technical expertise at the local level but also cultural and psychological ones. Relevant knowledge, timely information, and varied expertise (legal, technical, organizational, etc.) were identified as key success factors in the process. When internally available and transmitted by trustworthy sources these had proved to significantly change the owners' readiness to participate in the process and to mobilise collective action. The importance of matching mandatory responsibilities at the local level with appropriately allocated funding and incentives was repeatedly underlined by all the participants contacted by the researchers during the roundtables, discussion panels and on-site 
visits. Strategic thinking and a long-term vision on the whole life cycle of the urban project appeared largely missing in a process of immense urgency, addressing complex settings of interactions in an existing built environment. That compromised the long-term sustainability of the projects.

\subsubsection{Capacity for collective action and leadership}

The homeowners of the multifamily houses in Bulgarian cities had been experiencing the difficulties of high energy expenses and low living comfort. They were thus pressed to accept the mandatory collective action determined by the character of the building structures and requested by the funding schemes introduced at the national level. The number of households required to apply together for funding support had been, however, often coming to 120 or more. Homeowners' associations and municipal administrations thus faced a major challenge in mobilizing numerous actors of different social and economic status with no initial practical experience and capacity for collective action in the field of housing. The three real-life situations analysed in-depth in Sofia, each one of different time interval, targets set, funding options used, building structures addressed, actors involved, and action undertaken, were a chance to identify the common success factors under varying context. That was further related to the results from the interviewbased study at the municipal level of Burgas, which enabled a direct face-to-face contact with actors of different positions and various points of view collaborating with local HOAs. The inherited and still considerable social diversity of the inhabitants in the housing units proved to be a key strength in undertaking collective action in the multifamily houses. Well-educated experts and highly motivated individuals among the homeowners in were estimated by the respondents from the three casestudies in Sofia as being the key drivers in the refurbishment process - they were strategically thinking and capable to estimate potential benefits, to act fast and to put effective efforts in overcoming fears, shortsightedness and scepticism among their neighbours, to prepare application documents, communicate with local administration and building companies, etc. These were usually elected as members of the newly established HOAs, taking the leading role in a long process evolving under general uncertainty and unpredictable changes of rules and prices. The establishment of HOAs itself was considered a crucial step in the process as they could officially represent the homeowners in all the communication with authorities and service providers and to take responsibility for the control over the refurbishment process and its results. In all the casestudies the capacity for collective action was built upon proactive personal and collective attitude and required continuous team working. Homeowners' diverse technical and economic competences were harnessed in the process, strategic and operational thinking capacities were complementing each other, different people were leading and following along the path of what researchers have named "leadership-as-practice [79] (Raelin, 2020). For a successful partnership at the local level the homeowners needed to overcome the general distrust to public authorities inherited from socialism and the local administration had to develop new communication skills and to provide flexible and creative responses to emerging challenges. Thus, where estimated as successful, the overall results of the refurbishment process in the multi-family houses in Bulgaria had gone beyond the energy-related considerations; individuals as members of formal and informal collectives had gained self-confidence by the positive outcomes of their efforts and the local energy-related action resulting from the complex interaction of various factors, had hopefully encouraged a new culture of living together in the urban environment.

\subsection{ECHOES research experience in understanding the local urban context in Bulgaria}

Being multidisciplinary and multicultural, EU-funded ECHOES research project provided a chance and motivation to the Bulgarian research team for better knowing and understanding our own national context. It provided the time and resources to trace the 
dynamics of the ongoing urban process within a longer time span, but also proved the urgency of building a relevant capacity for interdisciplinary urban research, still missing in the country, and largely underestimated by national policy-making institutions. Some significant research gaps were identified and only partially addressed by the current study; it would, hopefully, open a debate on needed further research and policy efforts in the meting area of housing, urban policy and planning, and energy considerations.

\section{Conclusion: Energy Transition Context Matters}

The reported research experience in Bulgaria on the ongoing implementation of practical measures for energy-transition in the multi-family housing field, provides the ground for several important messages addressing a variety of institutions and communities involved at different levels in the process to energy transition. The research-funding institutions at the European, regional, and national level, and the multidisciplinary urban research community need a concise research strategy and agenda, well-focused on a contextually rooted process, which would require interdisciplinary and transdisciplinary approaches to enable a better knowledge and understanding of the real-life complexity and contribute to the effectiveness of the research recommendations to policy and practice. A greater sensitivity at all the policy levels - from EU to regional and local, to the diversity of socio-cultural factors on the ground and to voices coming from bottom-up would be crucial in support to energy-sensitive housing policies. Integrated urban approaches, however, need to be explicitly encouraged and energy considerations carefully considered throughout the whole life cycle of all policies, programmes, and projects. The research also provided the arguments in support of a recent reminder to all actors on the road to energy transition: "rather than learn best practices, skills, or competencies using case examples other than their own "case," participants would need to learn how to address and solve their own problems in their own settings, such as via action learning [78] (p. 3). Confronting real-life problems on the ground would require that the existing capacity for local self-organization is explicitly valued and supported and responsibilities are adequately taken under the peculiar spatial and socio-cultural context.

Author Contributions: Conceptualization and methodology, E. Dimitrova; formal analysis, E. Dimitrova, M. Tasheva-Petrova, A. Burov, I. Mutafchiiska; investigation, E. Dimitrova, M. TashevaPetrova, A. Burov, I. Mutafchiiska; initial writing - E. Dimitrova, M. Tasheva-Petrova, A. Burov, I. Mutafchiiska; writing - review and editing, E. Dimitrova, M. Tasheva-Petrova; visualization, E. Dimitrova, A. Burov. All authors have read and agreed to the published version of the manuscript.

Funding: This research was funded by EC, Horizon 2020 programme, ECHOES project ("Energy CHOices supporting the Energy Union and the Set-Plan"), 2016-2019, Grant agreement Nr: 727470.

Acknowledgments: The authors express their gratitude to all the members of ECHOES research consortium for the fruitful discussions on methods and results; to the colleagues involved in organizing and documenting the on-site studies in Bulgarian municipalities; to the participants in the discussion panels, round tables and interviews who dedicated time and effort to present and discuss real-life process, challenges, and efforts in renovating multifamily residential buildings in Bulgaria.

Conflicts of Interest: The authors declare no conflict of interest. 


\section{References}

1. UNCCC. Glasgow Climate Pact, 2021. Available at: https://unfccc.int/sites/default/files/resource/cop26_auv_2f_cover_decision.pdf (last accessed on 21/12/2021)

2. EC/COM(2014)15 final/2. Communication from the Commission to the European Parliament, the Council, the European Economic and Social Committee and the Committee of the Regions. A policy framework for climate and energy in the period from 2020 to 2030, 2014. Available at: https://eur-lex.europa.eu/legal-content/EN/ALL/?uri=CELEX:52014DC0015 (last accessed on 27/12/2021)

3. CEC/COM (2015) 6371 final. Towards an Integrated Strategic Energy Technology (SET) Plan: Accelerating the European Energy System Transformation, 2015. Available at: https://ec.europa.eu/energy/sites/ener/files/documents/1 EN ACT_part1_v8 0.pdf $=04$ (last accessed on 16.12.2021)

4. $\mathrm{EC} / \mathrm{COM} / 2010 / 0639$ final. Communication from the Commission to the European Parliament, the Council, the European Economic and Social Committee and the Committee of the Regions. Energy 2020. A strategy for competitive, sustainable, and secure energy, 2010. Available at: EUR-Lex - 52010DC0639 - EN - EUR-Lex (europa.eu)

5. ECHOES project. ECHOES project (“Energy CHOices supporting the Energy Union and the Set-Plan"), Horizon 2020 programme, 2016-2019, Grant agreement Nr: 727470, Available at: https://echoes-project.eu/

6. CEC/COM (2006) 847 final. Towards a European Strategic Energy Technology (SET) Plan. Available at: https://eur-lex.europa.eu/LexUriServ/LexUriServ.do?uri=COM:2006:0847:FIN:EN:PDF (last accessed on 16.12.2021)

7. EC/COM(2011) 885 final. Energy Roadmap 2050, 2011. Available at: https://eur-lex.europa.eu/LexUriServ/LexUriServ.do?uri=COM:2011:0885:FIN:EN:PDF (last accessed on 27.12.2021)

8. EC (European Commission). Report of the Meeting of Advisory group ICT Infrastructure for energy-efficient buildings and neighbourhoods for carbon-neutral cities. Brussels, 2011. Available at: https://ec.europa.eu/information_society/activities/sustainable growth/docs/smart-cities/smart-cities-adv-group report.pdf (last accessed on 30.12.2021)

9. Bin, S., H. Dowlatabadi,. Consumer lifestyle approach to US energy use and the related CO2 emissions. Energy Policy, 2005, 33(2), pp. 197-208; doi:10.1016/S0301-4215(03)00210-6

10. Wei, Y.-M., L.-C. Liu, Y. Fan, and G. Wu. The impact of lifestyle on energy use and CO2 emission: An empirical analysis of China's residents. Energy Policy, 2007, 35(1):247-257, doi:10.1016/j.enpol.2005.11.020.

11. Duarte, R., A. Mainar, and J. Sánchez-Chóliz. The role of consumption patterns, demand, and technological factors on the recent evolution of $\mathrm{CO} 2$ emissions in a group of advanced economies. Ecological Economics, 2013, 96:1-13, doi:10.1016/j.ecolecon.2013.09.007.

12. Martiskainen, M. Affecting consumer behaviour on energy demand, Final report to EdF Energy, Sussex Energy Group, SPRU - Science and Technology Policy Research, 2007. Available at: http://citeseerx.ist.psu.edu/viewdoc/download?doi=10.1.1.463.7249\&rep=rep1\&type=pdf (last accessed on 16.12.2021)

13. Lutzenhiser, L. Social and behavioural aspects of energy use. Annual Review of Energy and the Environment, 1993, 18, pp. 247-289, doi:10.1146/annurev.eg.18.110193.001335.

14. Jackson, T. Motivating sustainable consumption. a review of evidence on consumer behaviour and behavioural change. Technical report, University of Surrey, UK, 2005. Available at: http://sustainablelifestyles.ac.uk/sites/default/files/motivating sc final.pdf (last accessed 27.12.2021)

15. Sanquist, Thomas F., Heather Orr, Bin Shui, Alvah C. Bittner. Lifestyle factors in U.S. residential electricity consumption, in Energy Policy, 2012, vol. 42, pp. 354-364. Available at: https://doi.org/10.1016/j.enpol.2011.11.092 (last accessed on 16.12.2021)

16. Linden, S. van der, E. Maibach., A. Leiserowitz. Improving Public Engagement with Climate Change: Five "Best Practice" Insights from Psychological Science. In Perspectives on Psychological Science, 2015, 10(6), pp.758-763, doi: 10.1177/1745691615598516.

17. Mortensen, P. Heiselberg, M. Knudstrup. Identification of key parameters determining Danish homeowners' willingness and motivation for energy renovations, International Journal of Sustainable Built Environment, 2016. Volume 5, Issue 2, December 2016, pp. 246-268, http://dx.doi.org/10.1016/j.ijsbe.2016.09.002.

18. IDEAS project (Intelligent neighbourhooD Energy Allocation \& Supervision), EU FP7, 2012-2015); Available at: https://cordis.europa.eu/project/id/600071 (last accessed on 30.11.2021)

19. Rode P., Keim C, Robazza G, Viejo P, Schofield J. Cities and Energy: Urban Morphology and Residential Heat-Energy Demand. Environment and Planning B: Planning and Design, 2014; 41(1):138-162. doi:10.1068/b39065

20. Repette, P.; Sabatini-Marques, J.; Yigitcanlar, T.; Sell, D.; Costa, E. "The Evolution of City-as-a-Platform: Smart Urban Development Governance with Collective Knowledge-Based Platform Urbanism", Land 2021,10(1), pp. 33. https://doi.org/10.3390/land10010033 (last accessed on 16.12.2021)

21. Klöckner, C., Andres, J., Chebaeva, N., Dimitrova, E., Frieden, D., Koksvik, G., Koljonen, T. Löfström, E., Qiu, X., Røyrvik, J., Tzanev, D., \& Velte, D. An Analysis of the Potential of Advanced Social Science Knowledge in Policymaking. ECHOES Report, 2018. Available at: https://echoes-project.eu/sites/echoes.drupal.pulsartecnalia.com/files/D\%203.3\%20final.pdf (last accessed on 30.11.2021)

22. Tounquet, F., De Vos, L., Goes, M., van Melle, T. Giordano, V., Rapoport, S. Consumer satisfaction KPIs for the roll-out of smart metering in the EU Member States. European Commission Directorate-General for Energy, Tractebel Impact, 2020. 
Available at: https://op.europa.eu/en/publication-detail/-/publication/74eb4281-509b-11eb-b59f-01aa75ed71a1/languageen?WT.mc id=Searchresult\&WT.ria_c=37085\&WT.ria f=3608\&WT.ria_ev=search (accessed on 30.11.2021)

23. EEA (European Environmental Agency). Achieving energy efficiency through behaviour change: what does it take? EEA Technical report No 5, 2013. Available at: https://www.eea.europa.eu/publications/achieving-energy-efficiency-through-behaviour/file (last accessed on 30.11.2021).

24. UNESCO. Universal Declaration on Cultural Diversity, 2001. Available at: http://portal.unesco.org/en/ev.phpURL ID=13179\&URL DO=DO TOPIC\&URL SECTION=201.html (accessed on 15.11.2021)

25. Hawkes, J. Challenges for local cultural development. In Pascual, Jordi, ed. Cities, cultures and developments: A report that marks the fifth anniversary of Agenda 21 for culture; United Cities and Local Governments, 2009, p. 67.

26. ICOMOS. Cultural Heritage for Achieving the Sustainable Development Goals: A Policy Guidance for All Cultural Heritage and Development Actors. Paris, 2021. Available at: https://www.icomos.org/images/DOCUMENTS/Secretariat/2021/SDG/ICOMOS SDGs Policy Guidance 2021.pdf (last accessed on 15.11.2021)

27. de Brauwer, C. et al. Building consensus for a citizen-driven Energy Union: understanding energy choice dynamics and their impact on energy governance in the EU. ECHOES Report D 7.1, 2019. DOI: 10.13140/RG.2.2.21318.63048 (accessed on 24.11.2021).

28. Biresselioglu, Mehmet Efe, Demir, Muhittin Hakan, Demirbag Kaplan, Melike, Solak, Berfu. An analysis of the parameters that determine the similarities and differences regarding the energy choices and energy related behaviour between different types of formal social units. ECHOES Report Deliverable 6.2, 2018. Available at: https://echoes-project.eu/sites/echoes.drupal.pulsartecnalia.com/files/D6.2.pdf (last accessed on 30.11.2021)

29. Lettmayer, G., S. Schwarzinger, G. Koksvik, T. M. Skjølsvold, D. Velte, E. Dimitrova, M. Tasheva-Petrova, A. Burov, I. Mutafchiiska M.E. Biresselioglu, M. H. Demir, B. Solak. The impact of "Energy memories" on Energy Cultures and energy consumption patterns. ECHOES Report 5.2, 2018. Available at: https://echoes-project.eu/sites/echoes.drupal.pulsartecnalia.com/files/D5.2.pdf (last accessed on 30.11.2021)

30. Bird, D. N., S. Schwarzinger, D. Kortschak, M. Strohmaier, G. Lettmayer. Comparative assessment report on European energy lifestyles. ECHOES 5.1.1 Report, 2019. Available at: https://echoes-project.eu/sites/echoes.drupal.pulsartecnalia.com/files/documents/ECHOES-D5.1 Energy evaluation methodology 191015 final.pdf (last accessed om 2021/12/27).

31. Sæther, Simen Rostad, Xinlu Qiu, Marianne Skaar, Jens Dalseth Røyrvik, Marie Nilsen, Asle Gauteplass, Jens Petter Johansen, Christian A. Klöckner, Espen Moe, Gitte Koksvik, Luitzen de Boer () Policy Recommendations: An analysis on collective and energy related decision-making processes of three formal social units. ECHOES Report Deliverable D6., 2018. Available at: https://echoes-project.eu/sites/echoes.drupal.pulsartecnalia.com/files/D6.1.pdf (last accessed on 30.11.2021)

32. Carrus, Giuseppe, Lorenza Tiberio, Angelo Panno, Gudrun Lettmayer, Ingrid Kaltenegger, Izaskun Jimenez Iturriza, Mehmet Efe Biresselioglu, Muhittin Hakan Demir, Berfu Solak, Elena Dimitrova, Milena Tasheva-Petrova, Irina Mutafchiiska, Angel Burov, Dragomir Tzanev, Ida Marie Henriksen, Tomas Moe Skjølsvold. (). Analysis of Enabling Factors for consumer action. ECHOES Report Deliverable 5.3, 2019. Available at: https://echoes-project.eu/sites/echoes.drupal.pulsartecnalia.com/files/D5.3.pdf (last accessed on 30.11.2021)

33. Iturriza, Izaskun Jimenez, Lucía Polo, Martin Beermann, Gudrun Lettmayer, Giuseppe Carrus, Lorenza Tiberio, Mehmet Efe Biresselioglu, Muhittin Hakan Demir, Berfu Solak, Elena Dimitrova, Milena Tasheva-Petrova, Irina Mutafchiiska, Angel Burov, Ida Marie Henriksen, Tomas Moe Skjølsvold. Collective energy practices in Europe. ECHOES Report, Deliverable D5.4, 2019. Available at: https://echoes-project.eu/sites/echoes.drupal.pulsartecnalia.com/files/D5.4.pdf (last accessed on 30.11.2021)

34. Biresselioglu, M. E., M. H. Demir, B. Solak, S. R. Sæther, M. Nilsen, X. Qiu, L. L. Manoz, E. Dimitrova, M. Tasheva-Petrova, I. Mutafchiiska, A. Burov, G. Lettmayer, M. Beermann, G. Carrus, L. Tiberio, A. Panno, L. P. Álvarez, I. J. Iturriza, P. Chokrai,T. Masson, S. Ulker, I. Atan, S. Correia, M. Åkerman, T. Koljonen. Suggestions and Recommendations for a Better Understanding of the Factors Driving Collective Energy Choices and Energy Related Behaviour, 2019. Available at: https://echoes-project.eu/sites/echoes.drupal.pulsartecnalia.com/files/D6.3.pdf (last accessed on 30.11.2021)

35. Ivanov, A. Geografia na energetikata na Bulgaria (Geography of Bulgaria's energetics), 2014. Available at: http://www.geoznanie.com/2014/02/blog-post 27.html (last accessed on 2021.12.20)

36. Energoproekt. Portfolio (in Bulgarian), 2015. Available at: http://energoproekt.bg/ENERGOPROEKT\%20ISC BG.pdf (last accessed on 2021.12.20)

37. Kozloduy NPP. Location and history, 2020. Available at: https://www.kznpp.org/en/about-us/location-and-history (last accessed on 2021.12.20).

38. Znepolski, I. (ed). NRB. Ot nachaloto do kraya (Peoples Republic of Bulgaria. From the beginning to the end) (in Bulgarian). The Institute for Studies of the Recent Past \& Ciela, 2011.

39. Kovacheva, R. Kogato nyamashe tok (When there was no electricity) (in Bulgarian), 2010. Available at: http://ralitsakovacheva.blogspot.com/2010/11/blog-post_08.html (last accessed on 2021.12.20)

40. Lakov, K. The Transition That Never Happened: At Least Not the Way That Was Recommended, IME, 2014. Available at: https://www.thetransitionthatneverhappened.info/var/TheTransitionThatNeverHappened-Book-Bulgarian-English.pdf (last accessed on 2021.12.20)

41. Lost Bulgaria. All pictures from 1990-2000: http://www.lostbulgaria.com/?cat=11 Accessed on 2021.12.20

42. Sabev, D. Sveshtena doyna krava, 2019. Available at: https://bodil.bg/2019/12/20/sacred-coal-cow/ Accessed on 2021.12.20

43. EVN Bulgaria. Kratka istoria na elektrifikatsiyata v Bulgaria (Brief History of electrification in Bulgaria), 2017. Available at: https://web.archive.org/web/20171225153240/https://www.evn.bg/Za-nas/Istoria.aspx (last accessed on 2021/12/20) 
44. CEZ Razpredelenie Bulgaria. Istoriya (History) (in Bulgarian), 2021. Available at: http://www.cez-rp.bg/bg/za-nas/istoriya (last accessed on 2021.12.20)

45. Greenpeace. Finansovite mini na „Kovachki (Kovachki's financial mines)(in Bulgarian). Sofia, 2018. Available at https://www.greenpeace.org/bulgaria/publikatsiya/1689/finansovite-mini-doklad/ (last accessed on 2021.12.20)

46. Neykov, S. Zaklyuchenia na moderatora. Forum „15 godini liberalizatsia na elektroenergiynia pazar - patyat napred“ (Moderator's conclusions. "15 years liberalization of the electric energy market - the way forward" Forum)(in Bulgarian), 2019. Available athttps://events.utilities.bg/2019/12/07/15-years-liberalization/ (last accessed on 2021.12.20

47. Government of the Republic of Bulgaria. Chapter 14 "Energy", 2001. Available at: http://old.europe.bg/en/htmls/page.php?category $=64 \&$ id $=327$ (last accessed on 2021.12.20)

48. CSD (Center for the Study of Democracy). The Energy Sector in Bulgaria: Major Governance Issues, 2010. Available at: www.csd.bg/fileSrc.php?id=20246 (last accessed on 21/12/2021).

49. Babourkova, R. The environmental justice implications of utility privatisation: the case of the electricity supply in Bulgaria's Roma settlements. In International Journal of Urban Sustainable Development, 2010, Vol. 2, Iss. 1-2 Pages 24-44, https://doi.org/10.1080/19463138.2010.511029 (last accessed on 17.10.2021)

50. EC Fact-finding mission. Report on findings and recommendations related to Bulgarian energy policy, 2013. https://www.mi.government.bg/files/useruploads/files/findings.pdf (last accessed on 17.10.2021)

51. EC. National Strategic Reference Frameworks (NSRF) for the period 2007-2013, 2007. Available at: https://ec.europa.eu/regional_policy/sources/atlas2007/fiche/nsrf.pdf (last accessed on 15.11.2021)

52. MEET (Ministry of Economy, Energy and Tourism). Energy Strategy of the Republic of Bulgaria till 2020. For Reliable, Efficient and Cleaner Energy, 2011. Available at: https://www.me.government.bg/files/useruploads/files/epsp/23 energy strategy2020\%D0\%95ng .pdf (accessed on 20.12.2021).

53. SEDA (Sustainable Energy Development Agency). “National Energy Efficiency Action Plan 2014-2020”, 2014. (In Bulgarian). Available at: www.seea.government.bg (last accessed on 04.06.2021).

54. MRDPW. Methodological Guidelines on Updating the Active Regional and Local Development Strategies and Plans, published by the Ministry of Regional Planning and Public Works, 2009. Available at https://www.mrrb.bg/static/media/ups/articles/attachments/85e5bca10edf4bce39cc99f7f87d6776.pdf (last accessed 27122021).

55. Dimitrova, E., K. Nakova. Urban aspects of energy efficiency: social dimensions and planning implications in current Bulgarian context. Proceedings, Technoport RERC conference, Trondheim, 16-18 April 2012.

56. Dimitrova, E. The MODEL (Management of Domains Related to Energy in Local Authorities) Project in Bulgaria, In Calzada, J.R., I. Kalteneger, J. Patterson, F. Varriale (eds). COST Action 1104 Smart Energy Regions - Skills, Knowledge, Training and Supply Chains, COST Association, Welsh School of Architecture, Cardiff University; 2016, pp. 72-77.

57. World Bank. Bulgaria Power Sector: Making the Transition to Financial Recovery and Market Liberalization: Summary Report, Reimbursable Technical Assistance, Copyright Bulgarian Energy Holding EAD, November 2016, available at: https://www.me.government.bg/files/useruploads/files/wb ras i summary report en.pdf (last accessed on 21.12.2021

58. Staykov, K. Households Energy consumption provided by EVN in the period 2009-2014. IME (Institute for Market Economy), Bulgaria, 2015. (In Bulgarian). Available at: http://ime.bg/var/images/Potreblenie 2015_Final.pdf (accessed on 24/06/2018).

59. Panayotova, D. 45 \% of the Bulgarians cannot afford normal heat comfort, 2016. In Bulgarian. Available at: https://news.bg/energy/45-ot-balgarite-ne-mogat-da-si-pozvolyat-normalno-otoplenie.html (last accessed on 30.11.2021)

60. Georgiev, A. Cross-Subsidies - the Archenemy of Liberalization", Public Services Knowledge Network, 10.06.2016. Available at: https://www.publics.bg/en/publications/297/Cross-Subsidies \%E2\%80\%93 the Archenemy_of_Liberalization.html (last accessed on 23.06.2018).

61. Zahariev, B., Grigorova, V., Iordanov, I. Energy Poverty in Bulgaria", Open Society Institute, Sofia, 2016. In Bulgarian. Available at: http://osi.bg/downloads/File/2016/energy4.pdf (last accessed on 24/06/2018)

62. OPRD (Operational Programme "Regions in Growth") (2014-2020), (in Bulgarian). Available at: http://www.bgregio.eu/opregioni-v-rastezh--2014-2020/obshta-informatsiya-za-oprr-2014-2020.aspx; version in English approved by EC, 2015. Available at: http://bgregio.eu/media/files/Programirane\%20i\%20ocenca/OPRG\%202014-2020 2014BG16RFOP001 1 3.pdf (last accessed on $27 / 12 / 2021$

63. NSI. Population and demographic processes in Bulgaria in 2020, 2021. Available at: https://www.nsi.bg/sites/default/files/files/pressreleases/Population2020 IVGTQG5.pdf (last accessed on 24.11.2021)

64. NCRD (National centre for regional development). National concept for spatial development for the period 2013-2025. The national space - our common heritage for the future, 2012. Available at: http://www.bgregio.eu/media/Programirane/NKPR_28012013_Last_en.pdf (last accessed on 24.11.2021)

65. Florczyk, Aneta J.; Corbane, Christina; Ehrlich, Daniele; Freire, Sergio; Kemper, Thomas; Maffenini, Luca; Melchiorri, Michele; Pesaresi, Martina; Politis, Panagiotis; Schiavina, Marcello; Sabo, Filip; Zanchetta, Luigi. GHSL Data Package 2019, Publications Office of the European Union, Luxembourg, 2019. DOI: 10.2760/0726.

66. Pesaresi, Martino; Florczyk, Aneta; Schiavina, Marcello; Melchiorri, Michele; Maffenini, Luca. GHS settlement grid updated and refined REGIO model 2014 in application to GHS-BUILT R2018A and GHS-POP R2019A, multitemporal (1975-1990-20002015), R2019A. European Commission, Joint Research Centre (JRC), 2019. DOI: 10.2905/42E8BE89-54FF-464E-BE7BBF9E64DA5218 PID: http://data.europa.eu/89h/42e8be89-54ff-464e-be7b-bf9e64da5218 (last accessed on 17.10.2021)

67. Bertaud, A. The Spatial Structures of Central and Eastern European cities: more European than Socialist? International symposium on post-communist cities. The Russian and East European Center (REEC), University of Illinois at Urbana- 
Champaign, 2004. Available at: https://citeseerx.ist.psu.edu/viewdoc/download?doi=10.1.1.800.2817\&rep=rep1\&type=pdf $($ last accessed on 27.12.2021)

68. NSI. 2011 Population Census - main results, Sofia, 2011.

69. BPIE (Buildings Performance Institute Europe). Accelerating the renovation of the Bulgarian building stock the present and future of the national energy efficiency programme for multifamily residential buildings, 2016. Available at: https://bpie.eu/wp-content/uploads/2016/05/Accelerating-the-renovation-of-the-Bulgarian-building-stock EN.pdf (last accessed on 27/12/2021)

70. World Bank () Housing Sector Assessment. Final Report prepared for Ministry of Regional Development and Public Works, 2017. Available at: https://documents1.worldbank.org/curated/en/776551508491315626/pdf/116518-REVISED-PUBLIC-BulgariaHousingAssessmentFinalReportEN.pdf (accessed on 27/12/2021)

71. Dimitrova, E., M. Tasheva-Petrova, I. Mutafchiiska, A. Burov. Energy-Related Policy in the Housing Sector of Bulgaria: In Search for a Meeting Point of Social and Technical Dimensions. IOP Conference Series: Earth and Environmental Science, 2019, Volume 329, conference 1, https://iopscience.iop.org/article/10.1088/1755-1315/329/1/012005 (last accessed on 24.11.2021)

72. RB/ME/MoEW (Republic of Bulgaria / Ministry of Energy/ Ministry of the Environment and Water). Integrated Energy and Climate Plan of the Republic of Bulgaria 2021-2030, 2021. Available at: https://ec.europa.eu/energy/sites/default/files/documents/bg_final necp_main en.pdf (last accessed on 21/12/2021).

73. SEDA. Policies and measures of energy efficiency in Bulgaria Monitoring energy efficiency targets of the EU and Bulgaria, ODYSSEE- MURE 2010: Detailed National Reports on Energy Efficiency and Policies, Sofia, 2012. Available at: www.odysseemure.eu/publications/national-reports/energy-efficiency-bulgaria.pdf (last accessed on 24.11.2021)

74. MRDPW (Ministry of Regional Development of Public Works) Report on the progress of implementation of the National programme on the energy efficiency of multifamily residential buildings in 2019, 2020 (in Bulgarian). Available at: https://www.mrrb.bg/bg/doklad-za-napreduka-po-izpulnenieto-na-nacionalna-programa-za-energijna-efektivnost-na-mnogofamilni-jilistni-sgradi-prez-2019-godina-i-prilojenie-kum-doklada/ (last accessed on 27.12.2021)

75. Energy Efficiency Act (EEA) adopted in 2015 and updated in 2021 State Gazette, issue 35/15.05.2015. Available at: https://www.ciela.net/svobodna-zona-darjaven-vestnik/document/2136500695/issue/5100/zakon-za-energiynata-efektivnost (last accessed on 17.10.2021)

76. Republic of Bulgaria Ministry of Energy () National Energy Efficiency Action Plan (NEEAP) 2014-2020. Updated 2017, Sofia. 2017. Available at: http://www.seea.government.bg/documents/TRA\%20BG\%20NEEAP\%202017\%20EN.pdf (accessed on 17.10.2021)

77. MRDPW (Ministry of Regional Development of Public Works). National Programme for Energy Efficiency in Multifamily Residential Buildings, 2017. Available at: https://www.mrrb.bg/en/energy-efficiency/energy-efficiency-of-multi-family-residential-buildings-national-programme/ (accessed on 27.12.2021)

78. MRDPW. Long-Term National Strategy to Support the Renovation of the National Building Stock of Residential and NonResidential Buildings by 2050, 2017. Available at: https://www.seea.government.bg/documents/bg ltrs 2020 en version.pdf (last accessed on 24.11.2021)

79. Raelin, J. In Leadership, Look to the Practices Not to the Individual. Academia Letters, 2020, Article 34. https://doi.org/10.20935/AL34, p.3 (last accessed on 17.06.2021). 